\title{
19th Century Pahang Islamic Scholars in 'A History of Pahang'
}

\author{
Amnah Saayah Ismail, B. Jalal and M. Md Saman \\ National Defense University of Malaysia \\ Sungai Besi Camp, 57000 Kuala Lumpur, Malaysia \\ amnah@upnm.edu.my,drburhan63@gmail.com, \\ mazurasaman74@yahoo.com
}

\author{
Wan Kamal Mujani \\ Department of Arabic Studies \& Islamic Civilization \\ Faculty of Islamic Studies \\ The National University of Malaysia, 43600 Bangi Malaysia \\ inawan@ukm.edu.my
}

\begin{abstract}
The 19th century saw an exciting development of Islam in Pahang. The development encompasses various aspects such as knowledge development, roles of scholars and the emergence of various Islamic institutions. This subject has been dwelled by several western writers; one of them was $W$. Linehan. Linehan dealt with this subject in his journal entitled "A History of Pahang", where he highlighted the prominence of several Islamic scholars such as Mufti Abdul Shukur, Kadi Ibrahim and Tuan Sanggang. This paper which employs content analysis and library studies will focus on Linehan's chronicle on several Islamic scholars including those from the Minangkabau tribe. Apart from the aforementioned scholars, there were also records of other scholars such as Tok Shihabuddin, Tok Mengkarak, Tuan Teh and others who were instrumental in propagating Islamic teachings in Pahang. Based on the records found in Linehan's journal, it can be concluded that the presence of Islamic scholars in Pahang can be traced back to the 19th century.
\end{abstract}

\section{Keywords—history, Islamic scholars, Pahang}

\section{INTRODUCTION}

The propagation of Islamic teachings in Pahang can be traced back as far as the 18th century where renowned scholars such as Tok Mengkarak, Tuk Makassar and others, established their own institutions where Islamic knowledge is taught to the local communities. Through their teachings, these scholars succeeded in establishing a solid Islamic foundation which became the backbone of the Malay communities in Pahang. The roles and contributions of these scholars in the 19th century were well documented by Linehan in "A History of Pahang”.

\section{A HistORY OF PAHANG}

“A History of Pahang” chronicled early historical events of Pahang. The contents of the journal amongst others provide narrations on Pahang's early history, aborigine tribes in Pahang, pre-Malaccan populace, the Malacca rulers of Pahang up to the year 1590, Sultan Abdul Ghafur, Pahang the province of Bendaharas' period (1699-1806), the rule of Bendahara Ali (1806-1857), the civil war (1857-1863), the Selangor war, Engku Muda Mansur, the mission of Swettenham and Clifford (1874-1887), the British agency, the early years of the Protectorate (1888-1891) and the revolt of Orang Kaya Semantan. "A History of Pahang" also includes attachments pertaining to the lineage of the early rulers of Pahang, families of the Bendahara and the modern day Sultan, principal chieftains, selected papers of Maharaja Perba, citations from Castanheda, photographs and maps. As the focus of this paper is on the progress of religious scholars in Pahang, Linehan's "A History of Pahang” is an important reference as it is considered a complete rendering of Pahang's history throughout the 19th century. It is also a credible journal as Linehan's primary source of reference includes records from the Colonial Office and letters of Maharaja Perba [1].

\section{The Progress OF Islamic SCHOLARS IN PAHANG DURING THE 19TH CENTURY ACCORDING TO “A HISTORY OF PAHANG”}

A few names of Islamic scholars were mentioned in "A History of Pahang” and there was a passage which indirectly depicts the existence of Islamic scholars and their efforts in propagating Islam in Pahang during the 19th century. Even though it was briefly mentioned, it helps in understanding the existence of Islamic scholars and their genealogy.

In the first instance where the existence of Islamic scholars and their roles in propagating Islam in Pahang was mentioned, Linehan wrote on the factors which made the new religion being accepted all over the state including the remote rural areas. One of the factors was the migration of the Minangkabaus at the second half of the 16th century. Evidence of tombs belonging to the Syeds in various parts of Pahang pointed to the existence of Islamic missionaries in the state. Islam prospered more in the areas surrounding the state capital but this did not mean that it was not accepted in the rural areas. The Minangkabaus were responsible in propagating Islam in the rural areas of Pahang.

Linehan also recorded the development of Islam in Pahang during the 19th century especially during the rule of Bendahara Ali. He wrote, "during the reign of Tun Ali, he has a Chief Minister who is also his son in-law Saiyid Omar or popularly known as Engku Saiyid. It was also during this time that Pahang had a Mufti, Tuan Haji Abdul Shukor and a Chief Kadi, Tuan Sanggang apart from numerous other religious teachers from a multitude of religious disciplines. Part of their routine task was to provide answers to Tun Ali on religious matters and to reinforce the religious beliefs of the ruler” [2].

The writings showed that religious adherence is not only restricted to the common people but also the rulers. Apart from 
the Mufti and the Chief Kadi in the state administration, there were numerous Islamic scholars who took the role of advising the ruler so that the administration of the state was in accordance with Islamic principles. These religious scholars played multiple roles in the society, not only they provide guidance in religious matters but they were also martial arts instructors, medicinal healers, house builders and traders. Due to their multi capabilities, they were revered by society.

Jang Aisjah referred the religionists as elite-magic-religious [3]. Gullick stated that the Sheikhs and Sayids were revered as they were perceived to be the descendants of the Prophet Muhammad p.b.u.h. [4]. According to Gullick, most of the Sayids were immigrants from the Acheh region in Northern Sumatera, Indonesia. They were very much revered so much so that they were able to marry into noble families including princesses. These Sheikhs and Sayids commanded a higher status compared to other elite-magic-religious. Gullick's statement supports Linehan's opinion on Islamic propagation and development in rural Pahang being championed by the Minangkabaus. Additionally, Abdullah Munsyi also mentioned about the Arabs in Pahang, where the Sheikhs and Sayids with their Arabic origins were held in high esteem by the Malays for their wealth and lineage [5]. This is evident when these Sheikhs and Sayids were given important positions not only in the society but also in the state administration. One such person is Sayid Omar or also known as Engku Sayid, the son in-law of Bendahara Tun Ali who was appointed as the Chief Minister.

Linehan's narration on the role of the Minangkabaus in propagating Islam in the rural areas of Pahang coincides with Zainal in his book Sejarah Islam di Pahang (The History of Islam in Pahang) in which Zainal highlighted several Minangkabau scholars or those originated from Java, Acheh and Bugis responsibled for propogating Islam in the districts of Bera and Temerloh [6]. Zainal also cited Syair al-Ghafilah, a poem written by Tok Shihabuddin which mentioned the name of an Islamic scholar, Tok Mengkarak (Imam Dzu al-Bayan, 1630-1730). Tok Mengkarak was called Imam Dzul al-Bayan which means a person which has the ability to clarify and explain issues. This is evident as he was able to explain, interpret and provide comparative examples of the teachings of Hamzah Fansuri. He was also credited with the establishment of an arbitration court which tried and convicted people who breach the law. His son, known as Tok Mengkarak II or Imam Nur Qadim (1670-1760) was also mentioned in Syair alGhafilah. He was a knowledgeable scholar who helped his father in Pahang's Islamic administration. He has many students all over the state which proved his prowess in Islamic knowledge. He succeeded his father as the second Mufti.

Another scholar who was influential and played an active role in the propagation of Islam in the rural areas of Bera and Temerloh was Imam Koming (d. 1800). He was bestowed with gifts from Sultan Ahmad as appreciation for helping the Sultan in governing the state. He was the first scholar to establish a religious school in Kampung Guai Bera. Due to his proficiency in Islamic knowledge, he was very much sought after by the local communities in their quest for Islamic knowledge. Kampung Guai Bera also produced a scholar by the name of Kadi Ismail (d. 1860) who eventually became the Kadi for Bera district.
Another religious scholar mentioned by Linehan was Mufti Haji A Shukur bin Haji Abd Kadir (1830). He was one of the many scholars involved in the propagation of Islam in Pahang. He was of Javanese lineage, born around 1770 and resided in Chenor. He received his early education from his father who was also a scholar educated in Mecca. Upon completing his studies under his father, he went to Mecca for a few years. Upon returning to Chenor, he established a religious school. Due to his prowess in Islamic knowledge, he was appointed as a Mufti in 1830 at the same time Kadi Abu Bakar Sanggang was appointed as the Chief Judge [7][8].

Kadi Abu Bakar Sanggang was also mentioned in W. Linehan's “A History of Pahang”. Apart from being a Kadi, he was also actively teaching. He was the first Kadi cited by Linehan to administer the Hulu Pahang area. One of his prominent students was Kadi Ibrahim who contributed greatly in the development of Islam in Pahang. In honor of his massive contributions, Sultan Ahmad I appointed him as the Chief Kadi of Pahang in 1890. He was also mentioned by Buyong Adil as Kadi Ibrahim who received a yearly salary of 180.00 [9]. He was the second Chief Kadi of Pahang after Kadi Abu Bakar Sanggang. Besides being the Chief Kadi, he has written several books such as Kitab Syifa' al-Abdan (3 volumes), Kitab Hidayatul al-Wildan, Tafsir Surah al-Ikhlas and al-Faaidaat Wa al-Muhaimmat. His legacy was continued by his son, Teh bin Abu Bakar, also known as Imam Perang Sanggang (1820-1900) who actively disseminated Islamic teachings in Pahang during the 19th century. He was also appointed as one of the Eight Chieftains of Pahang in the 1880s.

\section{SUMMARY}

The existence of Islamic scholars in Pahang can be traced back to the early centuries. These scholars were considered pillars in the state administration during their time. They were also revered personalities in society. Linehan in his journal cited the names of two religious scholars and a brief narration on the development of Islam in the rural areas of Pahang. The citations by Linehan proved that the scholars were not sidelined by the rulers and were actively involved in the state administration besides their main role of propagating and disseminating Islamic knowledge. The rulers maintained a close relation with the scholars so as to show their interest and concern regarding Islam being the religion of the majority. The close relation with the rulers facilitated their tasks of disseminating Islamic knowledge to the communities in Pahang.

\section{ACKNOWLEDGMENT}

This research was financially supported by The National University of Malaysia (Grant No. RACE-2015/2017-001) and National Defense University of Malaysia (RACE / F3P / PK5 / UPNM / 14).

\section{REFERENCES}

[1] W. Linehan, History of Pahang, JMBRAS, vol.XIV (part II), Singapore, 1974. 
[2] W. Linehan, "History of Pahang," JMBRAS, vol.XIV (part II), Singapore, 1936.

[3] Jang Asjah Muttalib, Pemberontakan Pahang 1891-1895 (Pahang Rebellion 1891-1895), Aman Press Publisher, Kelantan, 1972.

[4] J. M. Gullick, Malay society in the late nineteenth century, Oxford University Press, Singapura, 1989.

[5] Abdullah Munshi, Kisah Pelayaran Abdullah (The Story of Abdullah's Voyage), ed. Kassim Ahmad, Kuala Lumpur, Penerbit Fajar Bakti Sdn. Bhd. 1981.

[6] Zainal Hassan, Sejarah Islam Pahang 1750-2000 (Pahang's Islamic History 1750-2000), Temerloh, Pahang, n.d.
[7] A. S. Ismail, N. Z. Shah, W. K. Mujani \& I. S. Md Ressad, "Scholars' jihad ta'limi in Pahang during the 19th century," Middle - East Journal of Scientific Research, vol.20(12), 2142-2146, 2014 (DOI: 10.5829/idosi.mejsr.2014.20.12.21111).

[8] Wan Kamal Mujani et al., "Sultan Ahmad: the dilemma between the local rebels and British colonialists in Pahang at the end of the 19th century,” Asian Social Science, vol.10 (3), pp.205-210, 2014 (DOI: http://dx.doi.org/10.5539/ass.v10n3p205)

[9] Buyong Adil, Perjuangan Orang Melayu Menentang Penjajahan Abad ke15-19 (The Malay Struggle against Colonization during the 15th-19th Century). Kuala Lumpur: Dewan Bahasa dan Pustaka, 1983. 